DOI 10.18551/rjoas.2021-09.15

\title{
STRATEGY FOR STRENGTHENING THE COMPETITIVENESS OF VALUE CHAIN PINEAPPLE FARMING IN JAMBI PROVINCE, INDONESIA
}

\author{
Kaido Boris \\ Department of Resource and Environmental Economics, Graduate School \\ of Agricultural Science, Tohoku University, Sendai, Japan \\ E-mail: boris.kaido.s1@dc.tohoku.ac.jp \\ ORCID: 0000-0002-2208-5944
}

\begin{abstract}
Pineapple production is spread evenly throughout Indonesia, one of the widest pineapple farming cultivated by small farmers is in Jambi Province. However, the value chain was still a serious obstacle with the lengthy supply chain and existing intermediary traders. The direct survey was conducted in Tangkit village as the biggest pineapple production center. Data collection for this study was conducted during two field visits in September 2018 and June 2019 and continued with interviews in January and February 2020 using a snowball technique with 42 pineapple farmers, and 2 middlemen, 2 local traders, 2 wholesalers from outside the district of Jambi Province and 2 Pineapple processing local home industry players in the Tangkit village. Semi-structured interviews were conducted and completed with secondary data from previous research and literature from the same area. A Porter five forces model is used to develop better strategies by understanding and exploiting the conditions of pineapple farming. Research findings found that the pineapple products only focused on the local market. The pineapple can increase the value chain of pineapple farming by the strengths factor identified from the PFFM model. It will further strengthen the pineapple in the local market and the national market as a strategy to further enhance the competitiveness of the value chain in Jambi province.
\end{abstract}

\section{KEY WORDS}

Competitiveness, pineapple, value chain, strategy, farmers, PFFM model.

The agricultural sector is one sector that has a role important in the country's economy. The agricultural sector has a contribution to the pace of Indonesia's Gross Domestic Product (GDP) in 2015-2017 (BPS, 2018), where the agriculture sub-sector GDP is in the agriculture, forestry, and fisheries sectors based on the business field has an average value of $75.72 \%$ during the year 2015-2017. This value is the biggest compared to the subsector forestry and fisheries. In the agriculture, livestock, and agricultural services subsector, horticultural plants comprise fruits, vegetables, medicinal plants, and decorative plants. Fruits are commodities that have good potential to be developed. This is caused by the condition of the Indonesian climate tropics and the availability of resources that can support fruit development. One fruit that has become a superior commodity in Indonesia is pineapple, based on BPS (2018). The percentage of pineapple production in Indonesia in $2015-2017$ was $8.46 \%$ or ranked fourth in the production of fruits. Fruit production in Indonesia can be seen in Table 1. Horticultural products are a group of agricultural products traded and directly feel the impact of trade liberalization, which has historically horticultural products, has a strategic value for producers, traders, and consumers in Indonesia, where the market of horticultural products is relatively more open, with extensive market segmentation. Strategic environmental changes in the general economy, particularly the agricultural sector, also affect the market dynamics of horticultural products. It can be seen from the implications of trade liberalization and market integration, which encourages the growth of the modern market is becoming increasingly rapid, besides traditional markets. Pineapple, which is one of the flagship products of the horticultural commodity, has an economic value and high market demand. Based on data from the Indonesia DJHKP (2011), among the commodity fruits, pineapple has value and volume is the highest in the period 2003 - 2011. Indonesia is the fifth largest pineapple 
producer after Brazil, Thailand, the Philippines, and China. But the role of export pineapple Indonesia is no 19th with products that do not meet the world market standards. Pineapple production is spread evenly throughout Indonesia. In terms of productivity, in Jambi Province, there is a center of the largest pineapple-producing which is cultivated by small farmers. However, the value chain was still a serious obstacle with the lengthy supply chain and existing intermediary traders in this area. In line with Anggraeni 2016, one of the other fundamental problems existing in the pineapple farming in Indonesia is inefficient in the marketing system, value chain, and the relatively low yield quality of pineapple, or less qualified to be sold outside farming area. Therefore, this study aims to identify and develop value chain constraint strategies and to improve the competitiveness of the pineapple farming value chain in Jambi Province.

\section{METHODS OF RESEARCH}

The study was conducted in Tangkit village, Jambi province, Indonesia (Fig. 1). Data collection for this study was conducted during two field visits in September 2018 and June 2019 and continued with interviews in January and February 2020 using a snowball technique with 42 pineapple farmers, and 2 middlemen, 2 local traders, 2 wholesalers from outside the district of Jambi Province and 2 Pineapple processing local home industry players in the Tangkit village. Semi-structured interviews were conducted and completed with secondary data from previous research and literature from the same area. A Porter five forces model (PFFM) is used to develop better strategies by understanding and exploiting the conditions of pineapple farming better than others, which might achieve a sustainable competitive advantage (i.e., a more profitable position in the long term). The PFFM approach has been applied by Gold et al. $(2005,2006,2008)$ to describe the red cedar, chestnut, and shitake mushroom markets and has been proven successful in shedding light on specialty crop markets. The influence of governmental policies on the farming situation and market was added to the PFFM. The PFFM is illustrated in Figure 2.

\section{RESULTS AND DISCUSSION}

Overview of Pineapple Production in Tangkit Village. In Tangkit village, based on primary data taken directly, the average farmer harvests pineapple in 3 times in 1 week, and in once harvest the average is 132.23 fruits, then in one month the average fruit is 1378.8 fruits and in one year the production of pineapple in Tangkit village is 16545.6 fruits/ha/year, or if it is added to the peak of the harvest period which can reach 2 times a year, the average production is predicted to reach 33091.2 pieces/ha/year, as a comparison of production from year to year can be seen in table 2. Table 2 shows that the productivity of pineapple in Tangkit village from 2013 to 2017 has exploded with an increase in planting area from year to year. The area of pineapple planting in Tangkit village in 2013 covering an area of 820 ha with productivities of 37.54 tons/ha, 2014 there was an additional planting area of 10 ha, where productivity also increased 100\% from the previous year, in 2015 the planting area increased by 15 ha with increased productivities over $100 \%$ from the previous year which was 90.07 ha, in 2016 the planting area increased by 5 ha with the productivity of $7.39 \%$ which was $12.64 \mathrm{Ton} / \mathrm{ha}$ from the previous year and in 2017 did not experience extensive additions from the previous year, but there was an increase in productivity by $40 \%$ from the previous year at 257.16 ton/ha. In 2018, there was a decline in production from the interviews conducted. Farmers acknowledged that their crop production was very far down because many farmers could not afford to buy fertilizer. After all, fertilizer prices were very expensive while scarcity in the market subsidized fertilizers from the government, which resulted in farmers surrendering not to fertilize their land and resulting in low production. Consistent with Komarek et al., 2017 stated that lower open-market fertilizer prices appear to benefit smallholder farmers, and had the positive income effect at lower prices of fertilizers. Coupled with very poor production facilities and production road infrastructure that severely hampered the production of pineapple in Tangkit village and also the situation that happened 
in Tangkit village, many farmers have converted the function of their land into fish ponds so that the arable land for pineapple has diminished considerably, from the results of interviews got, over 2000 fish ponds have been built in the Tangkit village.

Pineapple and Livelihood Welfare Impact. Almost all the villagers work as pineapple farmers in this village, and the vast expanse of pineapple farming is still seen as blanketing in this area. Pineapple commodity that develops in Tangkit village is the major source of income for the population and is an area that is quite successful in increasing the income of farmers from pineapple cultivation. In addition, this village is also referred to as the pineapple production center village area and as the largest pineapple producer area in Jambi province. Pineapple commodity produced in Tangkit village is a superior variety and received an award from the Indonesian Minister of Agriculture named pineapple variety Tangkit. In addition, there is also a large pineapple monument mascot that is in the center of Tangkit Village and becomes the identity that Tangkit village is a pineapple-producing village to add economic value to pineapple fruit. Most of the villager's process pineapple into various processed products by opening a home industry that is managed by women. These processed pineapple products such as pineapple fritters, pineapple jam, taffy pineapple, and pineapple chips can increase family income. Harun et al. (2013) show that the Bugis ethnic Jambi community has a typical food as fried rambutan, pineapple jam, and fried pineapple jam. This food is produced by most Bugis ethnic who live majority in this area.

The development of the pineapple cultivation business has not been optimally pursued because of some problems. Problems faced such as the market of pineapple are constrained to marketing access because of poor road conditions and pineapples are purchased at very low prices. Community knowledge is still limited to pineapple management so that when farmers harvest together, the consequences of overproduction occur. This affects the low level of productivity, income, and community welfare. To maintain and develop agricultural businesses also need the use of social resources, this is because there are individual limitations in the control of production resources as material capital. Limited control of production resources as material capital, especially control of land, financial and technological resources, requires efforts to empower social resources as a potential for local resources, which includes local structural and institutional aspects. The development of social capital is very important because it will contribute to efforts to develop agribusiness and simultaneously empower local communities (Gede, 2009). Fresh pineapples are sold in local markets and among traditional markets in the cities in Jambi Province and outside the Jambi Province. Jakarta, Padang, and Palembang Cities are the major destinations for the pineapple Tangkit village market share (Indonesian Rural Ministry, 2017). Tamba (2017) revealed that the increase in crop productivity from year to year is because of the better farmers in conducting pineapple farming activities, namely from the application of farming techniques that start from seed preparation to post-harvest from pineapple commodities. The increase in crop productivity from year to year is because of the better farmers in conducting pineapple farming activities. Broadly, the population in the Tangkit village relies heavily on the pineapple plantation sector with an area of over 1,000 ha and the fisheries sector, namely 2,000 ponds. Some indicators that can explain the level of welfare in this village can be seen from the existing public facilities and those that have not been included, as presented in tables 3, 4, and 5. The table above shows, it can be seen that this village already has several education facilities, this is sufficient for primary and secondary education, most of the farmer's children attend school from the elementary to the middle level while still attending the school that has been built in this village. However, for advanced schools such as high school, the children of farmers must go to the Jambi city as the capital of Jambi Province, which is not too far away from Tangkit village, they go by motorized vehicle. Likewise, with health facilities in this village that already have several basic facilities for the farmer who experience pain and for pregnant women (Farmer' wife), farmers can check regularly with health facilities that have been provided and built by the local government, but for farmers who have a serious illness, they must be taken to a provincial central hospital because of the absence of adequate hospitals for more serious illnesses and require further treatment. Interestingly, for electricity facilities, almost all households in this village have 
been electrified by the state. This is very helpful for farmers to reduce expenditures for their households compared to farmers having to use fuel and buying power generation equipment for daily farmers.

Farming Size Characteristic and Value Chain Network Formed. Farming size can affect the number of crops that are harvested. Based on the interview conducted in September 2018, this farming has already become the second generation, as a legacy from the farmer's parents and the size is not large. Soentoro and Kliwon (1981) stated that the land in Indonesia is important as a set for rural communities because it can deliver a natural resource that can be managed into a source of income, with larger size of farming it is mean that farmers can produce a big amount of products and it will give an impact to profit and improve household welfare livelihood in the future, the size of land farming from pineapple farmer can be seen in table 6 . To support their daily income, the farmers conduct intercropping such as areca nuts, oil palm and develop other sources of income like fish ponds, easy to sell at the nearest market. As a traditional farmer, any attempt to enrich or improve their livelihoods requires an integrated value chain approach. The United Nations stated sustainable livelihoods could serve as an integrating factor that allows policies to address development, resistant resource management, and poverty eradication simultaneously (Krantz, 2001). Several economic actors who played a role and were involved in the value chain were Farmers as producers of production, then followed by middlemen, local small home pineapple processed industries, local retailers, local traders, wholesalers who came from outside the village. Figure 3 illustrated the value chain in Tangkit village.

Analysis of the Forces That Drive Improvement Pineapple Value Chains for Small Farmers Livelihood. The survey provided information about the forces that drive improvement in the pineapple value chain. The PFFM served as a framework for examining the competitive resources found in pineapple farming in Tangkit village. Table 7 presents information from actors involved in the value chain in the pineapple business in the Tangkit village. The results of the survey will be discussed for each of Porter's five forces plus the impacts of governmental policy. A descriptive representation of the forces and their influence on the pineapple value chain has been developed (see fig. 4).

Threat of New Entrants. To enter or build pineapple farming in Tangkit village requires many funds, especially for the scale of new farmers who want to build pineapple farming and want to compete with existing farmers. Most pineapple farmers have their land that is derived from the inheritance of their parents. The facts in the field got from interviews conducted that the price of land in the Tangkit village has been very expensive and many of the farmers who already have farming cannot expand their land because of the unavailability of capital to buy new land and the land is very limited. Likewise, at the buyer level (middlemen, local traders, wholesalers, or local home industry) to build or buy yields of farmers, farmers are already closely interwoven with tribal factors. The middlemen are people of the same tribe is almost $90 \%$ of the villagers are immigrants from the Sulawesi Island, and this factor makes it difficult for unknown players to enter the industry or pineapple farming in the Tangkit village. The middlemen usually have a contractual relationship and buy the harvest of the farmers at the beginning, the middlemen give the initial money for the capital of planting pineapple plants to the farmers, then the farmers' yields have been bound by a purchase contract at the beginning, this causes the relationship between farmers and buyers to be very strong. Thus, pineapple small farmers have a powerful position in competition with newcomers. The embodiment of the threat of new entrants can be seen in table 8.

Bargaining Power of Buyers. Buyers are the people or organizations who create demand in an industry (Mihaela et al. 2012). There are varieties of actors who are involved in this pineapple farming, starting from middlemen, local traders, wholesalers, local retailers, and local small home pineapple processes. The role of these buyers is very dominant because the bargaining position of farmers is very weak. Farmers are unable in terms of capital, to run one planting season from pineapple plants requires many costs, especially for meeting fertilizer needs. This weakness is filled by the role of buyers who have strong capital and have access to market demand that is always stable. On the other side, with this pattern, the farmers benefit because farmers have the power in terms of farmers' crop yields will be 
consumed by the market. However, farmers cannot have a good role in bargain prices. To reduce the dependence of the role of the buyer and the farmer can get a good price and still maintain a good relationship with the buyers can be made and provide good quality pineapple yields, prepare a steady supply of pineapple to the buyer, and resulting the price got by the farmers high (Gold et al., 2008). The embodiment of the bargaining power of buyers can be seen from the following table 9 .

Bargaining Power of Supplier (Farmer). Suppliers are the individuals and businesses that provide the raw materials to be transformed into goods provided to consumers. Supplier or producer, in this case, farmers are the pioneer in creating products in this industry. Suppliers' bargaining power is high when the market is dominated by few large suppliers rather than many fragmented sources of supply when there are no substitutes for the input, and when switching costs from one supplier to another is high (Porter, 1980). The position of farmers in the pineapple industry is very strong, to become a farmer in this village is difficult, farmers become the initial deciding where the value chain then anchors to buyers, and the strength of farmers is that they have land which is the main condition in starting the pineapple business as a supplier. Plus, pineapple farmers in Tangkit village have long been cultivating pineapple. They plant pineapple plants from the seeds they cultivate themselves, and this becomes a strength or characteristic of the products of farmers or suppliers in Tangkit village. The embodiment of the bargaining power of suppliers (farmers) can be seen from the following table 10.

Competition (Intensity of Rivalry among Existing Competitors). Rivalry can take many forms, such as price discounts, recent product introductions, advertising campaigns, and service improvement. This force describes the intensity of competition between existing businesses in the market. Intense rivalry exists if there are many participants about the same size and capacity in the market or if there are low market growth rates (Porter, 1980). Because it is limited by limited suppliers, the competition that occurs at the supplier level is not higher, but from other regions also has been cultivating pineapple plants but different from the varieties planted in the Tangkit village. In Tangkit village, pineapple produce with the primary purpose is to be ready to eat. However, in other regencies, varieties are cultivated with different objectives, namely for the pineapple processing industry, because the cultivated pineapple has a taste that is not so sweet compared to pineapple cultivated by farmers in this Tangkit village. Meanwhile, the competition is likely to occur is at the level of local retailers, the results of local home products processed industry derivatives, because of the increase in the growth of local supermarkets in Jambi city, and the local home industry is predicted to increase. The impact the home industry owners can choose and determine, according to an analysis of profit and loss in their favor, where their pineapple processed products will be sold. The embodiment of competition can be seen in table 11 .

Threat of Substitute. A threat of substitutes exists if there are alternative products with lower prices, better quality nutritional benefits, and availability that can be used for the same purpose (Porter, 1980). Tangkit village's pineapple can stand out very much for the local market (Jambi Province and Muaro Jambi Regency market). This pineapple is well known and the specialty of sweet pineapple taste and the ability of plants to adapt in peat lands. It makes the first choice for farmers to cultivating pineapple varieties where most of the land in the Tangkit village is peat type land. Processed products such as pineapple taffy, jam, and local snack processed food made from pineapple. Most of them use pineapple raw materials from Tangkit village. That factor substitute will not be a major obstacle to the survival of pineapple farming and the value of pineapple farming in Tangkit village. The embodiment of the threat of substitutes can be seen in table 12.

Policies That Influence the Farming. General support offered for small farms and direct marketing to consumers is helping the industry to expand its marketing reach. Lots of research from local Jambi University and many counseling programs carried out by the local government in providing information and training farmers in cultivating pineapple plants that can help pineapple farming in Tangkit village become even more advanced. Likewise, the ongoing certification process of the Geographical Indication Certificate (Gl) will make pineapple products from this village increase the selling price in the market. However, many 
local governments are pushing for diversification of businesses from pineapple plants such as oil palm planting and mobilizing fish farming (catfish) in ponds. This increases the enthusiasm of farmers to convert their land from palm oil commodities and fish farming in ponds. This can make a policy that inhibits and reduce the production of pineapple. The embodiment of the threat of substitutes can be seen in table 13.

\section{CONCLUSION}

The findings found that middlemen and wholesalers from outside have a significant role and power in pineapple farming. It results in small farmers involving value-added activities because of the concept of "business as usual". Pineapple in Tangkit village only focused on the local market, not on international markets. Intermediaries (middlemen and wholesalers) have a significant role in the value chain process. They play a role in setting the base price. The pineapple can provide income for small farmer livelihoods when using available resources with low capital investment while increasing the value chain of pineapple farming through the power identified from the PFFM model and continuing to maintain or strengthen factors that can further strengthen pineapple product in local markets and national markets as the further improvement strategy to lifting the competitiveness of the pineapple farming value chain in this village. Pineapple in this area is popular for its taste (sweet, nutritional, and medicinal properties), and trends in demand for this product at the retail, local consumer, local, and national market and individual consumption levels are increasing and prices are quite high. Some notable barriers to success in pineapple farming including as still traditional in the cultivation of pineapple plants, there is no renewal of pineapple crop improvement technology, the length of the harvesting period of pineapple causes this product to be seasonal, but can still be circumvented by rotating harvest time, highly dependent on nature when the weather is not good, or natural disasters (floods and fires) will have a very large negative impact, both for the production or sale and marketing of crops. The products produced are uneven in quality and the products are still monotonous, and the saturated market reach of this pineapple sales spread is only concentrated in the local province market. As a result, farmers could not use the internet to reach new marketing areas (Table 14). The finding provided valuable information about farming conditions, both in terms of strengths and weaknesses from production to marketing. It will be disseminated to farmers and buyers. To help the market grow, local universities, local government, and local agricultural extensions must continue to make production and market research, organize training, work with farmers and buyers to produce and ensure that only qualified products are offered for sale and continue to educate farmers about the importance pineapple farming in Tangkit village as the main livelihood and educate the consumer about the benefits of Tangkit's for increasing the small farmer's livelihood in Tangkit village.

\section{APPENDIX}

Table 1 - Fruit Production in Indonesia period 2015-2017

\begin{tabular}{|c|c|c|c|c|c|c|}
\hline \multirow[b]{2}{*}{ No } & \multirow{2}{*}{ Fruit } & \multicolumn{3}{|c|}{ Production (Ton) } & \multirow{2}{*}{ Total (Ton) } & \multirow{2}{*}{$\%$} \\
\hline & & 2015 & 2016 & 2017 & & \\
\hline 1 & Banana & 7162680 & 7007125 & 7299275 & 21469080 & 36.92 \\
\hline 2 & Mango & 2203791 & 1814550 & 2178833 & 6197174 & 10.66 \\
\hline 3 & Orange & 2165189 & 2014214 & 1744339 & 5923742 & 10.19 \\
\hline 4 & Pineapple & 1795985 & 1396153 & 1729603 & 4921741 & 8.46 \\
\hline 5 & Papaya & 7162680 & 904284 & 851532 & 2630924 & 4.52 \\
\hline 6 & Snake fruit & 953845 & 702350 & 965205 & 2621400 & 4.51 \\
\hline 7 & Durian & 795204 & 735423 & 995735 & 2526362 & 4.34 \\
\hline 8 & Jackfruit & 656583 & 654914 & 699495 & 2010992 & 3.46 \\
\hline 9 & Rambutan & 523700 & 572193 & 882628 & 1978521 & 3.4 \\
\hline 10 & Others & 2511572 & 2540213 & 2820820 & 7872605 & 13.54 \\
\hline
\end{tabular}

Source: BPS, 2018. 
Table 2 - Harvest Area, Pineapple Fruit Production and Productivity in Tangkit Village

\begin{tabular}{llll}
\hline Year & Harvest area $(\mathrm{Ha})$ & Production $($ Ton $)$ & Productivity $(\mathrm{Kg} / \mathrm{Ha})$ \\
\hline 2013 & 820 & 30.784 & 37.54 \\
2014 & 830 & 67.17 & 80.9 \\
2015 & 845 & 144.487 & 170.992 \\
2016 & 850 & 156.088 & 183.63 \\
2017 & 850 & 218.593 & 254.16 \\
\hline
\end{tabular}

Source: BPP Sungai Gelam Regency, 2018.

Table 3 - Education

\begin{tabular}{ll}
\hline Availability Level of Education & Percentage (\%) \\
\hline Kindergarten & 11.1 \\
Elementary School & 22.2 \\
Junior School & 22.2 \\
High School & 11.1 \\
Disability School & 0 \\
University & 0 \\
Vocational High School & 0 \\
Integrated Islamic School & 11.1 \\
Islamic elementary school & 11.1 \\
Seminary & 11.1 \\
\hline
\end{tabular}

Source: Indonesian Ministry of Village, Development of Disadvantaged Regions and Transmigration, 2017.

Table 4 - Health

\begin{tabular}{ll}
\hline Availability Health Facilities & Percentage (\%) \\
\hline Hospital & 7.1 \\
Maternity referral hospital & 7.1 \\
Health center with room & 7.1 \\
Health center without room & 7.1 \\
Branch health center & 0 \\
Polyclinic & 7.1 \\
Private doctor practice & 21.4 \\
Midwife practice & 7.1 \\
Village health center & 0 \\
Maternity hospital & 7.1 \\
Maternity \& child health center & 14.3 \\
Pharmacy store & 7.1 \\
Drug store & 7.1 \\
\hline
\end{tabular}

Source: Indonesian Ministry of Village, Development of Disadvantaged Regions and Transmigration, 2017.

Table 5 - Electrical

\begin{tabular}{ll}
\hline Availability Electrical Facilities & Percentage (\%) \\
\hline Private electrical & 0.7 \\
State Electrical & 99.3 \\
\hline
\end{tabular}

Source: Indonesian Ministry of Village, Development of Disadvantaged Regions and Transmigration, 2017.

Table 6 - Land Farming Size in Tangkit Village

\begin{tabular}{llll}
\hline No & Land ownership & Farmers & Percentage \\
\hline 1 & Very Small Scale $(0.5-1 \mathrm{Ha})$ & 2 & 6.7 \\
2 & Small scale $(>1-2 \mathrm{Ha})$ & 22 & 73.3 \\
3 & Medium $(>2.0-3.0 \mathrm{Ha})$ & 5 & 16.7 \\
4 & Rent & 2 & 6.7 \\
\hline
\end{tabular}

Source: Own Survey, 2018. 
Table 7 - Description of 50 respondents who participated in interviews (In Average)

\begin{tabular}{|c|c|c|c|c|c|c|c|c|}
\hline No. & Position & Product & $\begin{array}{l}\text { Business } \\
\text { Experience }\end{array}$ & Education & $\begin{array}{ll}\begin{array}{l}\text { Sales } \\
\text { (IDR) }\end{array} & \text { Price } \\
\end{array}$ & $\begin{array}{l}\text { Next Sales Price } \\
\text { (IDR) }\end{array}$ & Unit & $\begin{array}{l}\text { Next Sales } \\
\text { destination }\end{array}$ \\
\hline 1 & Farmers (42) & Fresh Pineapple & 19 & $\begin{array}{l}\text { Junior High School } \\
(53.33 \%)\end{array}$ & 2519 & 2519 & 1 & Middlemen \\
\hline 2 & Middlemen & Fresh Pineapple & 15 & Junior high school & 3000 & 4000 & 1 & $\begin{array}{l}\text { Local retailer, } \\
\text { Home industry }\end{array}$ \\
\hline 3 & Middlemen & Fresh Pineapple & 17 & High school & 3000 & 4000 & 1 & $\begin{array}{l}\text { Local retailer, } \\
\text { Home industry }\end{array}$ \\
\hline 4 & Local Trader & Fresh Pineapple & 10 & High school & 4000 & 5500 & 1 & $\begin{array}{l}\text { End consumer } \\
\text { (Local } \\
\text { market) }\end{array}$ \\
\hline 5 & Local Trader & Fresh Pineapple & 15 & High school & 4000 & 5000 & 1 & $\begin{array}{l}\text { End consumer } \\
\text { (Local traditional } \\
\text { market) }\end{array}$ \\
\hline 6 & Wholesaler & Fresh Pineapple & 16 & High school & 5000 & 10000 & 1 & $\begin{array}{l}\text { End consumer } \\
\text { (Outside Jambi } \\
\text { Province) }\end{array}$ \\
\hline 7 & Wholesaler & Fresh Pineapple & 14 & High school & 5000 & 10000 & 1 & $\begin{array}{l}\text { End consumer } \\
\text { (Outside } \\
\text { Province) }\end{array}$ \\
\hline 8 & $\begin{array}{l}\text { Home } \\
\text { Industry }\end{array}$ & $\begin{array}{l}\text { Pineapple } \\
\text { processed }\end{array}$ & 19 & Bachelor & $\begin{array}{l}\text { Fresh } \\
\text { Pineapple: } \\
1500\end{array}$ & $\begin{array}{l}\text { Finished } \\
\text { Product: } 13000\end{array}$ & 1 & $\begin{array}{l}\text { Local Supermarket } \\
\text { Retailer }\end{array}$ \\
\hline 9 & $\begin{array}{l}\text { Home } \\
\text { Industry }\end{array}$ & $\begin{array}{l}\text { Pineapple } \\
\text { processed }\end{array}$ & 20 & High school & $\begin{array}{l}\text { Fresh } \\
\text { Pineapple: } \\
1500\end{array}$ & $\begin{array}{l}\text { Finished } \\
13000\end{array}$ & 1 & $\begin{array}{l}\text { Local Supermarket } \\
\text { Retailer }\end{array}$ \\
\hline
\end{tabular}

Source: Based on field survey, 2019 and 2020.

Table 8 - Reflection of Threat New Entrants

\begin{tabular}{ll}
\hline Threat New Entrants & Power Value \\
\hline High investment & 10 \\
High farming cost & 9 \\
Emotional closeness of tribal & 9 \\
Market monopoly & 7 \\
Close relationship among grower \& buyer & 8 \\
\hline
\end{tabular}

Source: Own Survey, 2019.

Table 9 - Reflection Bargaining Power of Buyers

\begin{tabular}{ll}
\hline Bargaining Power of Buyers & Power Value \\
\hline Role of middle men is very strong & 10 \\
Local trader \& wholesaler have access to end customer & 9 \\
Home industry has contract with local retailer & 7 \\
Demand for fresh pineapple is higher than derived products & 9 \\
\hline
\end{tabular}

Source: Own Survey, 2019.

Table 10 - Reflection Bargaining Power of Supplier (Farmers)

\begin{tabular}{ll}
\hline Bargaining Power of Supplier (Farmer) & Power Value \\
\hline Only few new farmers & 10 \\
Strong tribal factor relationship & 9 \\
Pineapple fruit supply is limited & 8 \\
Product has prominent quality & 9 \\
\hline
\end{tabular}

Source: Own Survey, 2019.

Table 11 - Reflection of Competition

\begin{tabular}{ll}
\hline Competition & Power Value \\
\hline Not very Competitive & 9 \\
Possible to be monopolized by large cooperatives & 9 \\
Possible to be monopolized by big farmers, home industry & 9 \\
\hline
\end{tabular}

Source: Own Survey, 2019. 
Table 12 - Reflection Threat of Substitute

\begin{tabular}{ll}
\hline Threat of Substitute & Power Value \\
\hline Product stands out for its properties & 10 \\
Pioneer in specialty pineapple products & 10 \\
Popular Product & 10 \\
Recognized by central government & 7 \\
\hline
\end{tabular}

Source: Own Survey, 2019.

Table 13 - Reflection of Policies that Influence the Farming

\begin{tabular}{ll}
\hline Policies & Power Value \\
\hline Helpful policies & 7 \\
\hline Grants \& general support & 6 \\
Information \& support from local universities & 10 \\
The subsidy support program (fertilizer) & 9 \\
Certification (Gl certificate) & \\
\hline Unhelpful policies & 7 \\
\hline Replacement of other crops & 10 \\
Stimulates fish farming & \\
\hline
\end{tabular}

Source: Own Survey, 2019.

Table 14 - Summary of the Strengths and Weaknesses

\begin{tabular}{ll}
\hline Strengths of Tangkit Pineapple & Weaknesses of Tangkit Pineapple \\
\hline Popularity for taste, and nutrition and as the main & Conventional technology in agricultural cultivation \\
raw material for local specialties & Long time to harvest time (1year production period) \\
Sustainable & Seasonal production / although can be solved with \\
Abundant production & Rotation production \\
Fertile land & Dependence on natural wealth and weather \\
Local usage resources & Low-quality product \\
Abundant agricultural worker & Limited loan access to bank \\
Stable production supply for buyer & Need for strong and direct relationships \\
Demand is stable and increases & For end customers \\
Become the primary income for farmers and & There is no new market niche \\
buyers & There is no intention to open international markets \\
The selling price is quite high & The farmer does not understand about marketing through \\
The key supplier for local Markets & the internet and not proficient in English \\
\hline
\end{tabular}

Source: Own Survey, 2019.

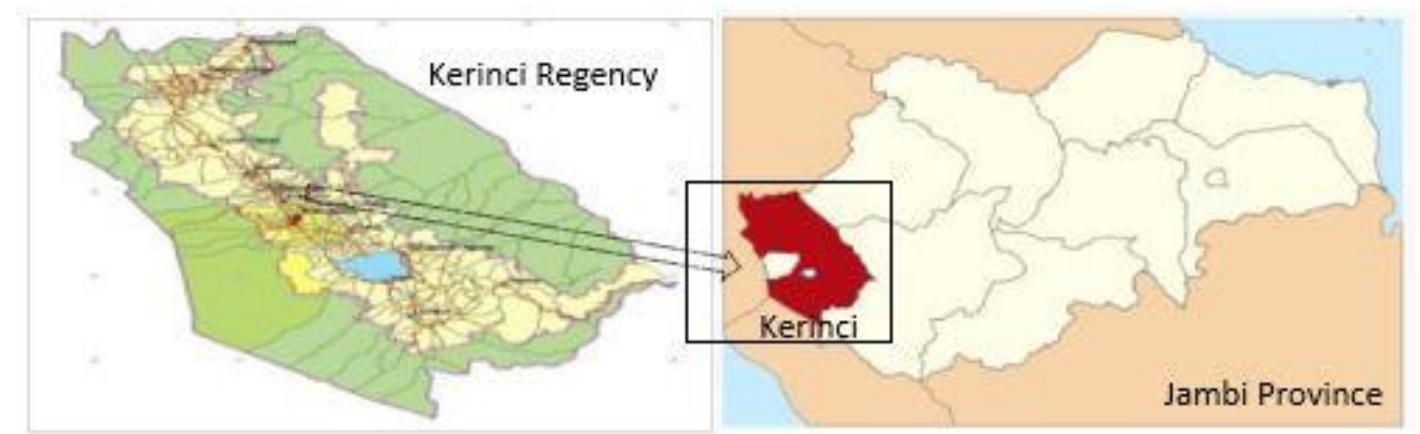

Figure 1 - Map of Kerinci Regency in Jambi Province (Source: Department of public works and the people/Dispupr, 2007) 


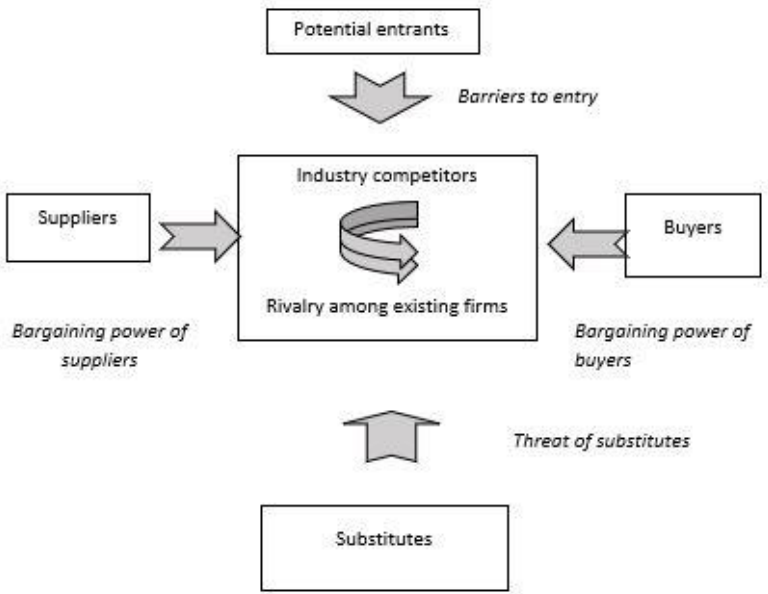

Figure 2 - The PFFM (Source: Porter, 1980)

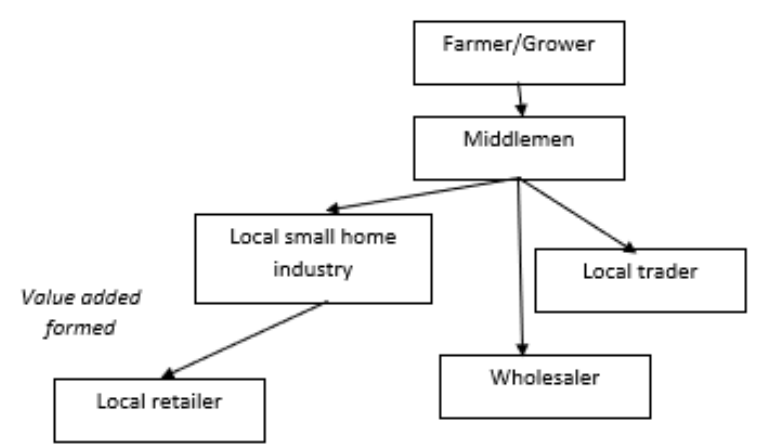

Figure 3 - Pineapple Value Chain in Tangkit Village (Source: Own survey, 2019)

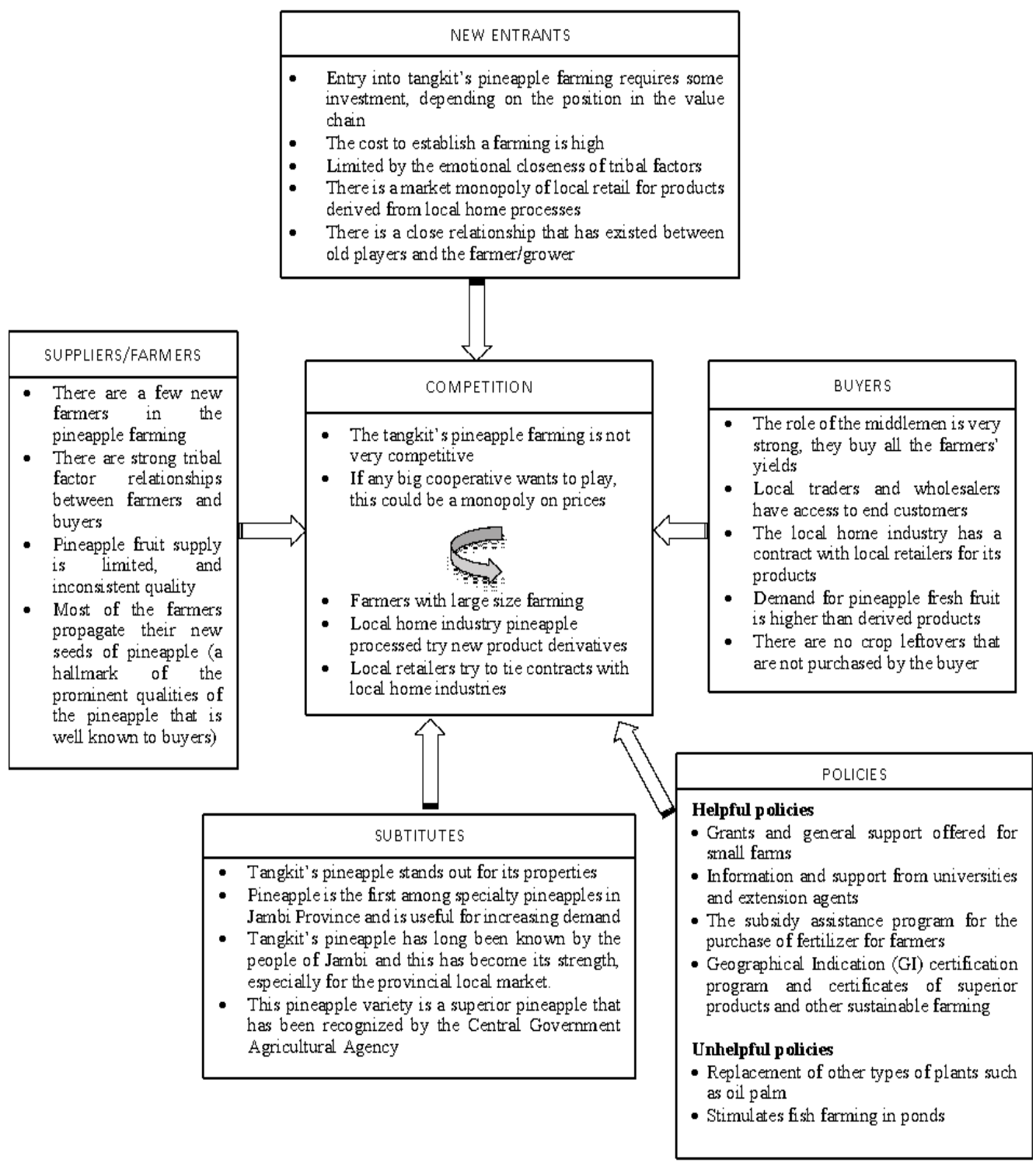

Figure 4 - Representation of the Influence of Porter's Five Forces on The Tangkit Village Pineapple Farming (Source: Own Survey, 2019) 


\section{REFERENCES}

1. BPP Sungai Gelam Regency, 2018. Harvest Area, Pineapple Fruit Production and Productivity in Tangkit Village. Muaro Jambi Regency.

2. BPS/Statistic Central Bureau. (2018). Statistical data of Jambi Province 2017. BPS: Jambi Province, p. 334.

3. DJHKP/Directorate General of Horticulture, Ministry of Agriculture. 2012. Horticultural Statistics 2011. Jakarta.

4. Gede, K. M. (2009). Social Networks in the Development of Agribusiness Systems and Enterprises: Theoretical Perspectives and Dynamics of Social Capital Studies. In the Agroeconomic Research Forum. (Vol. 27, No. 1).

5. Gold, M. A., Cernusca, M. M., \& Godsey, L. D. (2006). Competitive market analysis: chestnut producers. HortTechnology, 16(2), 360-369.

6. Gold, M. A., Cernusca, M. M., \& Godsey, L. D. (2008). A competitive market analysis of the United States shiitake mushroom marketplace. HortTechnology, 18(3), 489-499.

7. Gold, M. A., Godsey, L. D., \& Cernusca, M. M. (2005). Competitive market analysis of eastern redcedar. Forest Products Journal, 55(12).

8. Harun, M. H., Katutu, B., \& Yahya, S. R. (2013). The Bugis Diaspora in Sumatra. Tanjong Malim. Faculty of Language and Communication, Sultan Idris University of Education (UPSI).

9. Indonesian Ministry of Village, Development of Disadvantaged Regions and Transmigration, 2017. Tangkit Village. Jakarta.

10. Indonesian Rural Ministry, 2017. Featured Product of Tangkit Village. Jakarta. Indonesian Rural Ministry.

11. Komarek, A. M., Drogue, S., Chenoune, R., Hawkins, J., Msangi, S., Belhouchette, H., \& Flichman, G. (2017). Agricultural household effects of fertilizer price changes for smallholder farmers in central Malawi. Agricultural Systems, 154, 168-178.

12. Krantz, L. (2001). The sustainable livelihood approach to poverty reduction: An introduction. Swedish International Development Cooperation Agency, 25-31.

13. Mihaela, M., Cernusca, Gold, M. A., \& Godsey, L. D. (2012). Using the Porter model to analyze the US elderberry industry. Agroforestry systems, 86(3), 365-377.

14. Murni Anggraeni. (2016). Marketing System of Pineapple in Cijeruk Subdistrict Bogor Regency with Food Supply Chain Network Approach, Bogor: Press IPB University

15. Porter, M. E. (1980), Competitive strategy: techniques for analyzing industries and competitors. The Free Press, New York.

16. Soentoro, C. and Kliwon, K. 1981, Land Markets in Rural Java. In Policy Workshop on Agrarian Reform in Comparative Perspective, Sukabumi, May (pp. 17-30).

17. Tamba, L. R. (2017). The Relationship of Farmers Characteristics with the Application of Pineapple Farming Techniques in Tangkit Village, Sungai Gelam Sub District, Muaro Jambi District. Jambi. Press Jambi University.

18. Department of Public Works and the people (Dispupr). (2007). Kerinci Regency RP12JM document. Department of Public Works and the people of Kerinci Regency. Retrieved on December 27, 2020 from Dispupr Website: https://sippa.ciptakarya.pu.go.id/sippa_online/ws_file/dokumen/rpi2jm/DOCRPIJM_28853 4ae33_BAB\%20IBAB\%201Laporan\%20Penyusunan\%20Dok\%20RPI2JM\%20Kerinci\%2 02015.pdf 